\title{
An Overview on the Anti-inflammatory Potential and Antioxidant Profile of Eugenol
}

\author{
Joice Nascimento Barboza, ${ }^{1}$ Carlos da Silva Maia Bezerra Filho, ${ }^{1}$ Renan Oliveira Silva, ${ }^{2}$ \\ Jand Venes R. Medeiros $(\mathbb{D})^{3}$ and Damião Pergentino de Sousa $\mathbb{( i b}^{1}$ \\ ${ }^{1}$ Department of Pharmaceutical Sciences, Universidade Federal da Paraíba, 58051-970 João Pessoa, Paraíba, Brazil \\ ${ }^{2}$ Department of Biomedicine, University Center INTA-UNINTA, 62050-130 Sobral, Ceará, Brazil \\ ${ }^{3}$ Laboratory of Pharmacology of Inflammation and Gastrointestinal Disorders-LAFIDG, Federal University of Piauí, Parnaíba, \\ Piauí, Brazil
}

Correspondence should be addressed to Damião Pergentino de Sousa; damiao_desousa@yahoo.com.br

Received 6 July 2018; Accepted 3 October 2018; Published 22 October 2018

Guest Editor: Anderson J. Teodoro

Copyright (c) 2018 Joice Nascimento Barboza et al. This is an open access article distributed under the Creative Commons Attribution License, which permits unrestricted use, distribution, and reproduction in any medium, provided the original work is properly cited.

\begin{abstract}
The bioactive compounds found in foods and medicinal plants are attractive molecules for the development of new drugs with action against several diseases, such as those associated with inflammatory processes, which are commonly related to oxidative stress. Many of these compounds have an appreciable inhibitory effect on oxidative stress and inflammatory response, and may contribute in a preventive way to improve the quality of life through the use of a diet rich in these compounds. Eugenol is a natural compound that has several pharmacological activities, action on the redox status, and applications in the food and pharmaceutical industry. Considering the importance of this compound, the present review discusses its anti-inflammatory and antioxidant properties, demonstrating its mechanisms of action and therapeutic potential for the treatment of inflammatory diseases.
\end{abstract}

\section{Introduction}

Eugenol (4-allyl-2-methoxyphenol) is a phenolic compound from the class of phenylpropanoids and the main component of clove (Syzygium aromaticum (L.) Merr. \& L. M. Perry.). It consists of $45-90 \%$ of its essential oil [1]. It is used in the food industry as a preservative, mainly due to its antioxidant property [2], and as a flavoring agent for foods and cosmetics [3]. It can also be found in soybean (Glycine $\max$ (L.) Merr.), beans [4], coffee [5], cinnamon (Cinnamomum verum J. Presl), basil (Ocimum basilicum L.) [6], "canelinha" (Croton zehntneri Pax et Hoffm) [7], banana [8, 9], bay laurel (Laurus nobilis L.), and other foods [10]. Among the plants that contain eugenol, soybeans, cloves, beans, and cinnamon also present the antioxidant activity, possibly performed by this compound and other constituents [11-14]. In addition, clove is also known by anti-inflammatory activity [15], which may be related to anti-inflammatory action of eugenol (Figure 1).
Inflammation is a complex protective response of the body against harmful agents, such as microorganisms or damaged cells $[16,17]$, which the biological system objective to remove harmful stimuli from the body and promote healing. However, this response needs to be controlled and last for a short period; otherwise, it may provide the appearance of pathological disorders related to the immune system [18]. Classically, inflammation can be classified in acute and chronic. The acute inflammation is an initial response, which is characterized by resident cell activation, with liberation of proinflammatory cytokines and chemokines, culminating in the recruitment of polymorphonuclear, primarily neutrophils, from the innate immune system to the injury site. This response complex act to promote cardinal signs of inflammation, such as pain, edema, and heat [19]. On the other hand, chronic inflammation is a prolonged response characterized by a gradual change in the cells type found at the inflammatory site, which over time cause both 


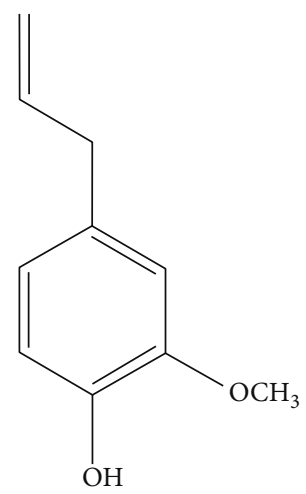

FIgURE 1: Chemical structure of eugenol.

permanent damage and healing of the tissue. In both types of inflammation occur increased local blood flow, vasodilation, fluid extravasation, and liberation of proinflammatory mediators $[17,20]$.

The nuclear factor-kappa B (NF- $\kappa \mathrm{B})$ signaling pathway is a key part of the immune response. It is essential to inflammatory processes due to its importance in the transcription of cytokines, such as tumor necrosis factor- $\alpha$ (TNF- $\alpha$ ), interleukin-1 $\beta$ (IL-1 $\beta$ ), interleukin-6 (IL-6), and nitric oxide (NO). Like eugenol, substances that inhibit this pathway are of interest to the pharmaceutical industry [21-23]. In general, patients with inflammatory disorders use clinically glucocorticoids or nonsteroidal anti-inflammatory drugs (NSAIDs). However, these drugs are associated with critical side effects (i.e., gastrointestinal ulcers and bleeding) and limited therapeutic efficacy, which often leads patients to abandon the treatment [24]. In this context, the pharmaceutical industry has directed efforts in the attempt to find new bioactive molecules.

Medicinal plants have been important sources of constituents with pharmacological activities. Phenylpropanoids are considered a group of secondary compounds found in a variety of plants and usually in the oxidized form, presenting a hydroxyl at the aromatic ring [25]. Studies recently demonstrated that phenylpropanoids and their synthetic derivatives have a variety of pharmacologic activities, including antiinflammatory action $[26,27]$.

Several pharmacological activities have been reported to eugenol: anti-inflammatory [28], antitumor [29], antibacterial [30], antifungal [31,32], antipyretic [33], anesthetic [34], and analgesic activities [35]. Considering the importance of eugenol as bioactive molecule and its presence in various foods and medicinal plants, this review discusses its role in the inflammatory response in experimental models, including animals and cell culture tests, demonstrating its antioxidant profile and potential therapeutical application against inflammatory diseases.

\section{Methodology}

The present review was based on the data search performed in the scientific literature database PubMed, using the publication from January 2008 to January 2018, using the following keywords: eugenol, asthma, antiasthmatic effect, allergy, antiallergic effect, inflammation, anti-inflammatory, immune response, lymphocytes, cytokines, immunoglobulins, immunoregulatory, and antioxidant. Table 1 shows the studies reported for this review and summarizes the results obtained, indicating the dose/concentration of eugenol administered, experimental model, parameters evaluated, and biological effect.

\section{Results and Discussion}

3.1. Antioxidant Action of Eugenol. The free radical scavenger effect of diphenyl-1-picrylhydrazyl (DPPH) is due to the ability of certain substances to donate hydrogen, especially those with a phenolic group in their structure. Thus, eugenol's ability to sequester free radicals in the DPPH assay $\left(\mathrm{IC}_{50}=11.7 \mu \mathrm{g} / \mathrm{mL}\right)$, as well as to inhibit reactive oxygen species (ROS) $\left(\mathrm{IC}_{50}=1.6 \mu \mathrm{g} / \mathrm{mL}\right), \mathrm{H}_{2} \mathrm{O}_{2}\left(\mathrm{IC}_{50}=22.6 \mu \mathrm{g} / \mathrm{mL}\right.$ and $27.1 \mu \mathrm{g} / \mathrm{mL}$ ), and $\mathrm{NO}\left(\mathrm{IC}_{50}<50.0 \mu \mathrm{g} / \mathrm{mL}\right)$ [36]. These data corroborate with other studies in which eugenol demonstrated DPPH sequestering activity with $\mathrm{EC}_{50}$ of $22.6 \mu \mathrm{g} / \mathrm{mL}$ [37]. In another study, it was able to eliminate about $81 \%$ of the DPPH radicals and reduce the potency of the radicals when the concentration decreased from $1.0 \mu \mathrm{M} / \mathrm{mL}$ to $0.1 \mu \mathrm{M} / \mathrm{mL}$ [38]. Similar data were described in the study by Kim et al., in which eugenol performed the elimination of ABTS free radicals $(76.9 \%$ at a dose of $20 \mu \mathrm{g} / \mathrm{mL})$ and DPPH $(90.8 \%$ at a dose of $20 \mu \mathrm{g} / \mathrm{mL})$ in L-ascorbic acid in $76.9 \%$ and $89.9 \%$, respectively [14].

In a comparative study of the antioxidant activity of clove and eugenol, both showed similar activities, with values of sequestering radicals DPPH and ABTS, respectively, $\mathrm{IC}_{50}=0.3257$ and $0.1595 \mathrm{mg} / \mathrm{mL}$ for the clove and of $\mathrm{IC}_{50}=0.1967$ and $0.1492 \mathrm{mg} / \mathrm{mL}$ for eugenol. Therefore, the antioxidant properties of this essential oil are related to the antioxidant action of its chemical constituent, which is eugenol [13]. The biochemical profile of this compound was confirmed in a study in which the antioxidant activity of eugenol was associated with anti-inflammatory activity. In this approach, Yogalakshmi et al. showed that pretreatment with eugenol $(10.7 \mathrm{mg} / \mathrm{kg} . \mathrm{bw} /$ day $)$ in rats for 15 days resulted in a decrease in lipid peroxidation indices, protein oxidation, and inflammatory markers (reduction in the expression of COX-2, TNF- $\alpha$, and IL-6) and by improving antioxidant status by maintaining antioxidants such as glutathione peroxidase $(\mathrm{GPx})$, superoxide dismutase (SOD), catalase (CAT), and glutathione-S-transferase (GST) [39]. Confirming these findings, a study by Kaur et al. showed that pretreatment with eugenol in male Swiss albino mice inhibited the expression of inflammatory markers such as iNOS and COX-2 and the cytokines IL- 6 , TNF- $\alpha$, and PGE2, as well as prevented the depletion of antioxidant enzymes and reduced lipid peroxidation (LPO), acting both as antiinflammatory and antioxidant agents [40]. In fact, eugenol pretreatment, in addition to reducing inflammation caused by lung exposure to LPS, was also able to significantly improve the levels of SOD1, CAT, Gpx1, and GST. Thus, eugenol can be used as an anti-inflammatory agent, as well as protecting the damage caused by oxidative stress [41]. 
TABLE 1: Modulation of inflammatory response mediated by eugenol.

\begin{tabular}{|c|c|c|c|c|c|}
\hline Experimental model & $\begin{array}{l}\text { Animal and/ } \\
\text { or cells lines }\end{array}$ & $\begin{array}{c}\text { Dose or } \\
\text { concentration } \\
\text { of eugenol }\end{array}$ & $\begin{array}{c}\text { Inflammatory parameters } \\
\text { evaluated }\end{array}$ & Biological effect & References \\
\hline $\begin{array}{l}\text { In vitro and in vivo } \\
\text { leukocyte migration } \\
\text { induced by fMLP, } \\
\text { LTB4, and } \\
\text { carrageenan }\end{array}$ & $\mathrm{BALB} / \mathrm{c}$ mice & $\begin{array}{l}0.5,1,3,9, \text { or } \\
27 \mu \mathrm{g} / \mathrm{mL} \\
62.5,125, \text { or } \\
250 \mathrm{mg} / \mathrm{kg}\end{array}$ & Leukocyte migration & $\begin{array}{l}\text { Decreased the number of } \\
\text { leukocytes that rolled, adhered, and } \\
\text { migrated to perivascular tissue }\end{array}$ & {$[50]$} \\
\hline $\begin{array}{l}\text { Model of allergic } \\
\text { asthma }\end{array}$ & $\mathrm{BALB} / \mathrm{c}$ mice & $\begin{array}{l}10 \text { or } 20 \mathrm{mg} / \\
\mathrm{kg}\end{array}$ & $\begin{array}{l}\text { Cytokines (IL-4 and IL-5) levels, } \\
\text { histological assessment, and } \\
\text { VDUP1/NF- } \kappa \text { B signaling pathways }\end{array}$ & $\begin{array}{c}\text { Inhibited OVA-induced } \\
\text { eosinophilia, recovered IL-4 and } \\
\text { IL-5 levels, inhibited P-I } \kappa \mathrm{B} \alpha \text {, NF- } \\
\kappa \mathrm{BP} 65 \text {, and p-NF- } \kappa \mathrm{BP} 65 \text { protein } \\
\text { levels, and increased VDUP1 and } \\
\mathrm{I} \kappa \mathrm{B} \alpha \text { protein levels. }\end{array}$ & {$[51]$} \\
\hline $\begin{array}{l}\text { LPS-induced } \\
\text { inflammatory } \\
\text { reaction in acute } \\
\text { lung injury }\end{array}$ & $\mathrm{BALB} / \mathrm{c}$ mice & 5 or $10 \mathrm{mg} / \mathrm{kg}$ & $\begin{array}{l}\text { Activities of antioxidant enzymes } \\
\text { (CAT, SOD, GPx, and GST) and } \\
\text { inflammatory markers (MPO, IL-6, } \\
\text { and TNF- } \alpha \text { ) and inflammatory cells } \\
\text { recruitment }\end{array}$ & $\begin{array}{l}\text { Reduced the IL- } 6 \text { and TNF- } \alpha \\
\text { expression, suppressed NF- } \kappa \text { B } \\
\text { signaling, decreased the leukocyte } \\
\text { recruitment, and increased the } \\
\text { protein levels (SOD, CAT, GPx, } \\
\text { and GST) }\end{array}$ & {$[41]$} \\
\hline $\begin{array}{l}\text { LPS-induced lung } \\
\text { injury }\end{array}$ & $\mathrm{BALB} / \mathrm{c}$ mice & $\begin{array}{l}160 \mathrm{mg} / \mathrm{kg} \\
\text { body }\end{array}$ & $\begin{array}{l}\text { Inflammatory cells, TNF- } \alpha \text {, and } \\
\text { NF- } \kappa \text { B levels }\end{array}$ & $\begin{array}{l}\text { Reduced the neutrophil } \\
\text { recruitment, macrophages, TNF- } \alpha \text {, } \\
\text { and NF- } \kappa \text { B expression }\end{array}$ & {$[52]$} \\
\hline $\begin{array}{l}\text { Diesel exhaust } \\
\text { particles induced } \\
\text { pulmonary damage }\end{array}$ & $\mathrm{BALB} / \mathrm{c}$ mice & $164 \mathrm{mg} / \mathrm{kg}$ & $\begin{array}{l}\text { Amounts of polymorpho (PMN) } \\
\text { and mononuclear cells, apoptosis, } \\
\text { and oxidative stress }\end{array}$ & $\begin{array}{l}\text { Prevented the PMN infiltration, } \\
\text { reduced apoptosis through caspase- } \\
3 \text { cleavage, but limited the effects on } \\
\text { oxidative stress }\end{array}$ & {$[53]$} \\
\hline $\begin{array}{l}\text { Ischemia/ } \\
\text { reperfusion (I/R) } \\
\text { injury }\end{array}$ & Wistar rats & $\begin{array}{l}10 \text { or } 100 \mathrm{mg} / \\
\mathrm{kg}\end{array}$ & $\begin{array}{l}\text { Inflammatory markers (MPO, } \\
\text { TNF- } \alpha \text {, and NF- } \kappa \text { B p65) and } \\
\text { oxidative stress (GSH and MDA) }\end{array}$ & $\begin{array}{l}\text { Reduced MPO, TNF- } \alpha, \mathrm{NF}-\kappa \mathrm{B} \text {, and } \\
\text { MDA. Eugenol also increased GSH } \\
\text { levels. }\end{array}$ & {$[54]$} \\
\hline $\begin{array}{l}\text { Isoproterenol- } \\
\text { induced myocardial } \\
\text { infarction }\end{array}$ & Wistar rats & $100 \mathrm{mg} / \mathrm{kg}$ & $\begin{array}{c}\text { Cells inflammatory infiltration, } \\
\text { oxidative stress, and protein } \\
\text { biomarker ( } \alpha 1, \alpha 2, \beta 1, \beta 2 \text {, and } \gamma \\
\text { globulin) }\end{array}$ & $\begin{array}{l}\text { Reduction of inflammatory cells } \\
\text { infiltration and mediators proteins, } \\
\text { increased SOD, GPx, and GSH, } \\
\text { with reduction of TBARS }\end{array}$ & {$[55]$} \\
\hline $\begin{array}{l}\text { LPS-induced } \\
\text { inflammatory } \\
\text { signalizing }\end{array}$ & $\begin{array}{l}\text { Macrophage } \\
\text { RAW } 264.7\end{array}$ & $\begin{array}{c}1,10,50, \text { or } \\
100 \mu \mathrm{M}\end{array}$ & $\begin{array}{l}\text { Inflammatory markers (NO, TNF- } \\
\alpha, \text { IL- } 1 \beta \text {, and NF- } \kappa \mathrm{B}) \text {, regulatory } \\
\text { enzymes (iNOS), and signal } \\
\text { transduction (Akt, ERK1/2, JNK, } \\
\text { and p38 MAPK) }\end{array}$ & $\begin{array}{c}\text { Reduced NO, TNF- } \alpha \text {, IL- } 1 \beta \text {, NF- } \\
\kappa \mathrm{B} \text {, and iNOS expression. Eugenol } \\
\text { also decreased the ERK } 1 / 2 \text { and p38 } \\
\text { MAPK signaling pathways }\end{array}$ & [57] \\
\hline $\begin{array}{l}\text { LPS-activated } \\
\text { peritoneal } \\
\text { macrophages }\end{array}$ & $\mathrm{BALB} / \mathrm{c}$ mice & $\begin{array}{l}0.31,0.62 \\
1.24, \text { or } \\
2.48 \mu \mathrm{g} / \mathrm{mL}\end{array}$ & $\begin{array}{l}\text { COX- } 2 \text {, NF- } \kappa \mathrm{B} \text {, and TNF- } \alpha \\
\text { expression in resting macrophages }\end{array}$ & $\begin{array}{l}\text { Promoted hypoexpression of TNF- } \\
\alpha \text {, but not COX- } 2 \text { or NF- } \kappa \mathrm{B}\end{array}$ & {$[58]$} \\
\hline $\begin{array}{l}\text { RANKL-induced } \\
\text { osteoclast formation }\end{array}$ & $\begin{array}{l}\text { RAW264.7 } \\
\text { murine } \\
\text { macrophages }\end{array}$ & $\begin{array}{l}50,100, \text { or } \\
200 \mu \mathrm{M}\end{array}$ & $\begin{array}{c}\text { Degradation of } \operatorname{IkB} \alpha \text { and NF- } \kappa \mathrm{B} \text {, } \\
\text { MAPK activation }\end{array}$ & $\begin{array}{c}\text { Attenuated the degradation of } \\
\text { IkBa, activation of NF- } \kappa \mathrm{B} \text { and } \\
\text { MAPK pathways }\end{array}$ & {$[5]$} \\
\hline $\begin{array}{l}\text { Alveolar bone } \\
\text { deformities in an } \\
\text { ovariectomized } \\
\text { (OVX) rodent model }\end{array}$ & Wistar rats & 2.5 or $5 \mathrm{mg} / \mathrm{kg}$ & $\begin{array}{l}\text { Histopathology and inflammatory } \\
\text { mediators (IL- } 1 \beta, \text { IL-6, and TNF- } \\
\alpha \text { ) }\end{array}$ & $\begin{array}{c}\text { Reduced the inflammatory cell } \\
\text { infiltrate, IL- } 1 \beta \text {, IL- } 6 \text {, and TNF- } \alpha \\
\text { levels }\end{array}$ & {$[60]$} \\
\hline $\begin{array}{l}\text { LPS-induced } \\
\text { inflammation }\end{array}$ & $\begin{array}{l}\text { Human } \\
\text { dental pulp } \\
\text { fibroblasts }\end{array}$ & $13 \mu \mathrm{M}$ & $\begin{array}{l}\text { Genes expression (NF- } \kappa \mathrm{B}, \mathrm{IL}-1 \beta \text {, } \\
\text { and TNF- } \alpha \text { ) }\end{array}$ & $\begin{array}{c}\text { Inhibition of TNF- } \alpha \text { expression and } \\
\text { NF- } \kappa \text { B signaling pathway, but not } \\
\text { IL- } 1 \beta \text { levels }\end{array}$ & {$[62]$} \\
\hline $\begin{array}{l}\text { Cutaneous chemical } \\
\text { carcinogenesis }\end{array}$ & Swiss mice & $15 \%(v / v)$ & $\begin{array}{c}\text { Inflammatory markers (IL-6, TNF- } \\
\alpha, \text { PGE }_{2} \text {, COX-2, and iNOS) and } \\
\text { oxidative stress (MDA, GSH, GPx, } \\
\text { GR, CAT, and GST) }\end{array}$ & $\begin{array}{l}\text { Reduced the IL-6, TNF- } \alpha, \mathrm{PGE}_{2} \text {, } \\
\text { COX, and iNOS levels. Eugenol } \\
\text { also decreased the MDA levels and } \\
\text { increased the GSH content and } \\
\text { activities of GR, CAT, GPx, and } \\
\text { GST }\end{array}$ & {$[40]$} \\
\hline
\end{tabular}


TABle 1: Continued.

\begin{tabular}{|c|c|c|c|c|c|}
\hline Experimental model & $\begin{array}{l}\text { Animal and/ } \\
\text { or cells lines }\end{array}$ & $\begin{array}{c}\text { Dose or } \\
\text { concentration } \\
\text { of eugenol }\end{array}$ & $\begin{array}{c}\text { Inflammatory parameters } \\
\text { evaluated }\end{array}$ & Biological effect & References \\
\hline $\begin{array}{l}\text { Ability to interfere } \\
\text { with cell growth }\end{array}$ & HeLa cells & $300 \mu \mathrm{M}$ & $\begin{array}{c}\text { Genes expression (COX-2 and IL- } \\
1 \beta)\end{array}$ & $\begin{array}{l}\text { Reduced the COX- } 2 \text { and IL- } 1 \beta \\
\text { expression }\end{array}$ & {$[63]$} \\
\hline $\begin{array}{l}\text { Cisplatin-mediated } \\
\text { toxicity }\end{array}$ & $\begin{array}{l}\text { MDA-MB- } \\
\text { 231, MDA- } \\
\text { MB-468, and } \\
\text { BT-20 cells }\end{array}$ & $\begin{array}{l}0.25,0.50 \\
0.75,1.0, \text { or } \\
1.5 \mu \mathrm{M}\end{array}$ & $\begin{array}{c}\text { Gene expression (NF- } \kappa \mathrm{B}, \mathrm{IL}-1 \beta \text {, } \\
\text { and TNF- } \alpha \text { ) }\end{array}$ & $\begin{array}{c}\text { Reduced NF- } \kappa \text { B, IL- } 1 \beta \text {, and TNF- } \alpha \\
\text { expression }\end{array}$ & {$[23]$} \\
\hline $\begin{array}{l}\text { Postoperative } \\
\text { alveolar osteitis in } \\
\text { patients having third } \\
\text { molars extracted }\end{array}$ & Human & $\begin{array}{l}0.2 \% \\
\text { chlorhexidine } \\
\text { gel, a eugenol- } \\
\text { based paste }\end{array}$ & $\begin{array}{l}\text { Postoperative pain, inflammation, } \\
\text { infection, and wound healing }\end{array}$ & $\begin{array}{l}\text { Reduced the incidence of alveolar } \\
\text { osteitis, pain, inflammation, } \\
\text { infection, and better wound healing } \\
\text { compared to control group }\end{array}$ & {$[65]$} \\
\hline $\begin{array}{l}\text { Carrageenan- } \\
\text { induced paw edema }\end{array}$ & Rats & 1,2, or $4 \%$ & Paw edema & $\begin{array}{l}\text { Inhibited the inflammation, } \\
\text { reducing the edema }\end{array}$ & {$[64]$} \\
\hline
\end{tabular}

3.2. Can Eugenol Reduce the Inflammatory Response via Its Antioxidant Action? Oxidative stress is a condition that reflect an imbalance between biological defensive and aggressive system, mediated by excessive production of reactive oxygen species (ROS), e.g., $\mathrm{O}^{2-}$ (superoxide radical), $\mathrm{OH}$ (hydroxyl radical), and $\mathrm{H}_{2} \mathrm{O}_{2}$ (hydrogen peroxide), in which there is an inability of the antioxidant mechanisms to neutralize them [42]. This process results in toxic effects and alterations of the normal redox state, which is associated with cellular damage and lipid peroxidation [43].

Studies have shown that inflammation and oxidative stress are interconnected phenomena, which are involved in pathological conditions as cardiovascular [44], kidney [45], liver disease [46], and cancer [47]. In this way, during inflammatory events occur exacerbated production of ROS in the damaged inflammatory tissue, which can stimulate and had a critical role in the signaling pathway for inflammatory mediators production, such as proinflammatory cytokines and chemokines, resulting in inflammatory cell migration [48].

Thus, compounds capable of modulating oxidative stress may contribute to reduce critical mediators in inflammatory events act as anti-inflammatory agents, even by indirect way. So, several research groups have demonstrated that eugenol has anti-inflammatory and antioxidant capacity, and therefore, be more effective in reducing inflammation.

3.3. Eugenol Reduces the Inflammatory Response and Ameliorate the Function of Specific Organ. The antiinflammatory effect of eugenol has been investigated in the leukocytes migration using different stimuli, such as $\mathrm{N}$-formyl-methionyl-leucyl-phenylalanine (fMLP), leukotriene B4 (LTB4), and carrageenan. Polymorphonuclear (PMN) recruitment to the inflammatory site occurs dependent on a complex response involving the endothelium-leukocyte interactions and subsequent extravasation to the inflamed site [49]. In this background, Estevão-Silva and colleagues [50] demonstrated that eugenol significantly decreased the in vitro and in vivo leukocytes migration in response to chemotactic factors by the modulation of rolling and adherence to perivascular tissue. In addition, the authors showed that eugenol did not induce changes in cell viability, which suggest absence of toxic effect [50].

Additionally, Pan and Dong [51], using an experimental model of allergic asthma induced by ovalbumin (OVA), demonstrated that eugenol administration inhibited the OVA-induced eosinophilia in the lung tissue, prevented the increased of IL-4 and IL-5 levels, and reduced the $\mathrm{NF}-\kappa \mathrm{B}$ signalizing pathways. According to the authors, the inflammatory response reduction had a pivot role in the antiasthmatic effect of eugenol, resulting in the decrease of airway resistance (AWR) [51]. This data suggests that eugenol can be a therapeutic and strategic agent in patients with asthma.

Eugenol also has anti-inflammatory activity on lipopolysaccharide- (LPS-) induced acute lung injury. Pretreatment with eugenol inhibited the inflammatory response and leukocyte recruitment into the lung tissue by the downregulation of proinflammatory cytokines (IL- 6 and TNF- $\alpha$ ) expression and $\mathrm{NF}-\kappa \mathrm{B}$ signaling. In addition, eugenol also increased the superoxide dismutase (SOD), catalase (CAT), glutathione peroxidase $(\mathrm{GPx})$, and glutathione-S-transferase (GST), which are important antioxidative enzymes [41]. Similarly, Magalhães and colleagues [52], using an animal model of LPS-induced lung injury for 6 hours, demonstrated that eugenol significantly reduced neutrophil infiltration, TNF$\alpha$, and the NF- $\kappa \mathrm{B}$-mediated signalizing pathway, decreasing the lung inflammation, resulting in an improved lung structure and function, which suggest an important drug to treat disorders of lung inflammatory diseases [52].

So, eugenol reduces the inflammatory response in animal model pulmonary damage caused by diesel exhaust particles. Eugenol administration reduced the pulmonary inflammation by inhibiting the PMN infiltration and apoptosis through caspase- 3 cleavage but limited the effects against oxidative stress. This resulted in the improvement of airspace collapse and pulmonary mechanics, which are evaluated by pneumotachography and altered by diesel particles [53]. These data demonstrated the potential of eugenol as an agent to treat the damage effects of air pollutant exposure, by mechanisms mediated, at the last in part, of its anti-inflammatory effects. 
Motteleb and colleagues (2014) conducted a study using eugenol to assess its efficacy in the prevention of liver damage in a model of ischemia and reperfusion (I/R). In this work, eugenol abolished the inflammation, reduced myeloperoxidase (MPO) activity, TNF- $\alpha$ levels, and NF- $\kappa$ B expression, and altered oxidative marker. It also reduced malondialdehyde (MDA) and increased GSH levels. This potent effect of eugenol resulted in the amelioration of hepatic structural and functional damage [54]. Thus, eugenol reduced the liver damage by the reduction of inflammatory mediators and modulation of redox status, suggesting a possible application against hepatic I/R injury.

Eugenol also was evaluated as preventive agent against cardiac remodeling following myocardial infarction. This pathology was induced using isoproterenol, which eugenol reduced inflammatory mediator's proteins and lipid peroxidation as well as increased antioxidative enzymes markers (i.e., SOD, GPx, and GSH). In this study, eugenol reduced cardiac injury biomarkers, such as troponin- $\mathrm{T}$, creatine kinase-muscle/brain (CK-MB), and $\mathrm{LDH}$, resulting in the improvement of electrocardiographic and hemodynamic parameters, and great potential antithrombotic, anti-inflammatory, and anti-ischemic activities [55].

\subsection{Eugenol Inhibits the Liberation of Inflammatory} Mediators from Macrophages. Macrophage is one of the immune system cells that contribute to the production of mediators (i.e., proinflammatory cytokines and nitric oxide), which are important to cellular and vascular events during the installation and progression of inflammatory process [56]. Thus, studies have demonstrated that eugenol can modulate the macrophage functions and regulates negatively the inflammation.

Yeh and colleagues demonstrated that eugenol inhibits the inducible nitric oxide synthase (iNOS) expression from macrophages in response to LPS, culminating in the reduction of NO levels. Additionally, eugenol also reduced the TNF- $\alpha$ and IL- $1 \beta$ as well as the NF- $\kappa$ B, ERK $1 / 2$, and p38 MAPK signaling pathways [57]. In other study, de Paula Porto and colleagues [58] also reported that eugenol promotes the downregulation of TNF- $\alpha$ in LPS-activated macrophages, which are associated with antigenotoxic activity when DNA damage was induced with doxorubicin (DXR) [58]. Thus, this data suggests that the molecular mechanisms to anti-inflammatory effects of eugenol are mediated by the regulation of inflammatory mediators production from macrophages.

\subsection{Anti-inflammatory Effect of Eugenol Modulates the Bone} Remodeling. Several research groups have described the effect of eugenol as anti-inflammatory agent and its role modulator on bone remodeling. Deepak and colleagues [59], using cell culture preexposed to RANKL (a receptor activator of NF$\kappa \mathrm{B}$ ligand), demonstrated that eugenol prevented the osteoclast differentiation in a dose-dependent manner. Among the molecular mechanisms involved, the authors emphasized the downregulation of NF- $\kappa \mathrm{B}$ and MAPKs signaling pathways, which suggest its use in bone remodeling disorders, such as osteoporosis [59]. A recent study demonstrated that eugenol administration for twelve weeks attenuated the alveolar bone loss and remodeling associated with estrogen insufficiency using an ovariectomized (OVX) rat model, which is similar to what occurs after menopause in humans. The authors suggested that anti-inflammatory effect of eugenol had primary importance, since it was accompanied by the reduction of IL- $1 \beta$, IL- 6 , and TNF- $\alpha$ levels resulting in the reduction of inflammatory cell [60].

Additionally, the effects of eugenol against inflammatory response also have been investigated in dental pulp fibroblasts from extracted third molars. During permanent teeth extractions arise postoperative complications, such as alveolar osteitis, an inflammatory condition with delayed healing and persistent pain [61]. In this context, Martínez-Herrera and colleagues [62] reported that eugenol inhibited TNF- $\alpha$ expression and NF- $\kappa \mathrm{B}$ signaling pathway, but not IL- $1 \beta$, when fibroblasts was exposed to LPS, confirming its antiinflammatory property in bone disorders. Curiously, eugenol also induced inflammatory gene mild expression in fibroblasts absence of previous inflammation [62].

3.6. The Antitumor Effect of Eugenol Appears to Be Mediated, in Part, by Its Anti-inflammatory Activity. Kaur and colleagues [40] demonstrated that eugenol prevents the 7,12-dimethylbenz[a] anthracene- (DMBA-) and 12-O-tetradecanoylphorbol-13-acetate- (TPA-) promoted skin carcinogenesis. According to the authors, the molecular mechanism of eugenol is related to its anti-inflammatory properties, since reduced proinflammatory cytokine levels (i.e., IL-6 and TNF- $\alpha$ ) and inflammation enzymes marker (COX and iNOS) are associated with the modulation of redox status (Figure 2) with reduced MDA and increased antioxidative enzymes [40]. Thus, these data strongly suggest the chemotherapeutic potential of eugenol against carcinogenesis. In accordance with these data, studies have evaluated the efficacy of eugenol alone or combined with other agents. Using HeLa cells, a human cervical cancer line, Hussain and colleagues [63] demonstrated that eugenol alone promoted cell growth inhibition and increase the therapeutic efficacy when combined with gemcitabine (a standard drug). In the clinical use, it can decrease the side effects promoted by gemcitabine administration. These beneficial effects appear to be mediated by its antiapoptotic and anti-inflammatory effects, since it were associated with increased caspase- 3 activity and reduction of COX- 2 and IL- $1 \beta$ expression, respectively [63]. Additionally, a recent study reported that eugenol promotes cytotoxicity against breast cancer cells (TNBC) and animal model and synergistic chemotherapeutic effects with cisplatin. A key point in this effect was the inhibition of the NF- $\kappa \mathrm{B}$ signaling pathway, which resulted in the inhibition of the p50 and p65 subunits phosphorylation, and its consequence migration to the cellular nucleus, reducing IL6 and IL-8 levels [23].

3.7. Eugenol-Based Pharmaceutical Formulation and Its Antiinflammatory Effects. From the pharmacological potential of eugenol in the modulation of inflammation, its use has also been tested in pharmaceutical formulations. Experimentally, Esmaeili and colleagues [64], using an animal model of 


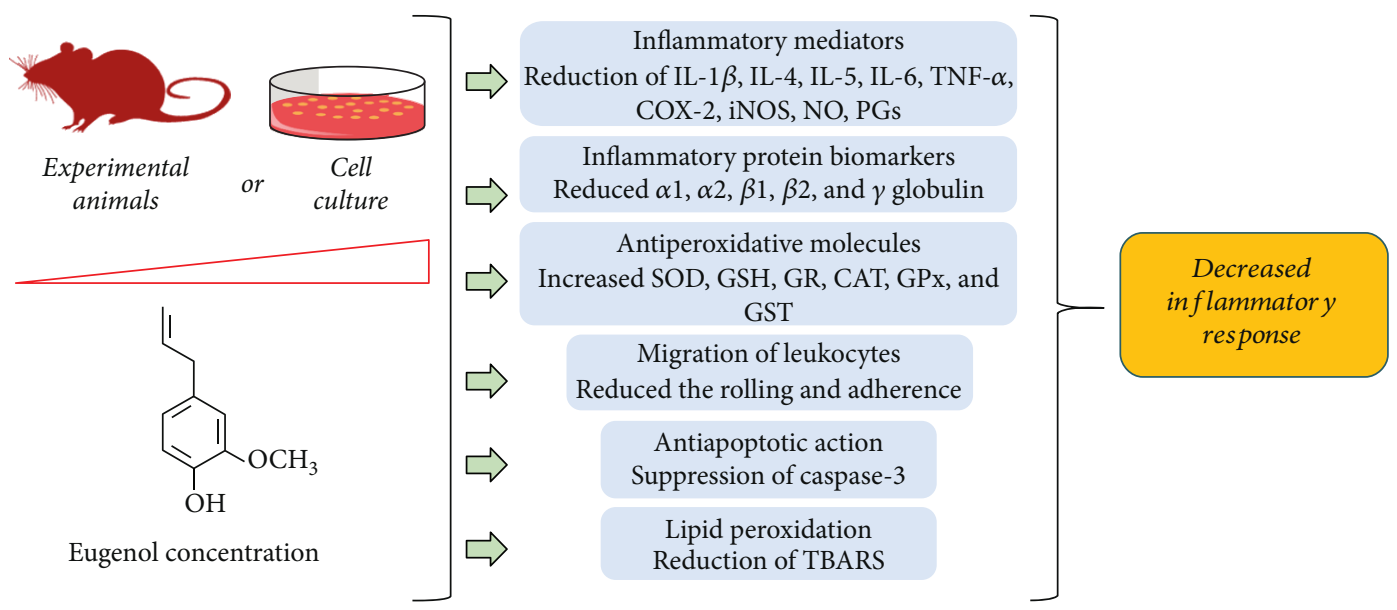

Figure 2: The effect of eugenol in the inflammation control.

carrageenan-induced edema, reported that a nano-emulsion containing $1 \%, 2 \%$, and $4 \%$ of eugenol reduced the edema formation and has increased efficacy when combinated with piroxicam, revealing a synergistic anti-inflammatory effect.

Additionally, a clinical dental study involving 270 patients having third molars extracted demonstrated that $0.2 \%$ chlorhexidine gel, a eugenol-based paste, reduced postoperative alveolar osteitis, pain, and time of wound healing compared to control group, but with better results when applied in two interventions [65].

3.8. Toxicity of Eugenol. Eugenol is known for its antioxidant, anti-inflammatory, antimicrobial, and antitumor activities; however, it may present some toxicity depending on the type of histological structure exposed to this compound and the concentration used [66]. Thus, eugenol toxicity was observed in human dental pulp fibroblasts from deciduous teeth, with DNA damage at concentrations ranging from $0.06-5.1 \mu \mathrm{M}$, which was not observed at higher interval concentrations of 320 to $818 \mu \mathrm{M}$ [67]. Eugenol was also able to induce genotoxicity by inducing DNA damage of mouse peritoneal macrophages at all concentrations tested $(0.62,1.24$, and $2.48 \mathrm{mg} / \mathrm{mL}$ ). However, it has demonstrated antigenotoxic potential depending on the treatment protocol, which may be interlinked with its effect on drug metabolism [58]. Therefore, eugenol can modulate inflammatory and oxidizing processes. However, its use must be made according to the therapeutic safety evidenced in toxicity.

\section{Conclusions}

This review demonstrates that eugenol exerts a beneficial action on oxidative stress through the inhibition of enzymes and oxidative processes, which is related to the antiinflammatory drug profile of this compound. The set of pharmacological studies reported evidences of the clinical potential of eugenol for the treatment of diseases associated with oxidative stress and inflammatory response. Considering the presence of this compound in foods and medicinal plants, the use of these vegetables can result in health benefits and consequently improvement in the quality of life.
However, advanced investigations are needed to understand its metabolism in the body and the contribution of metabolites in antioxidant action and possible interactions in receptors related to inflammation.

\section{Abbreviations}

ALDH: Aldehyde dehydrogenase

AP-I: Activating protein 1

AWR: Airway resistance

Bcl-2: B-cell lymphoma 2, apoptosis regulator

CAT: Catalase

CK-MB: Creatine kinase-muscle/brain

COX-2: Cyclooxygenase-2

DNA: Deoxyribonucleic acid

DMBA: 7,12-dimethylbenz[a]anthracene

DXR: Doxorubicin

$\mathrm{EC}_{3}$ : $\quad$ Estimated concentration

fMLP: Formyl-methionyl-leucyl-phenylalanine

GPx: Glutathione peroxidase

GSH: Reduced glutathione

GST: Glutathione-S-transferase

IFN- $\gamma$ : Interferon gamma

IL-1: Interleukin-1

IL-2: Interleukin-2

IL-4: Interleukin-4

IL-5: Interleukin-5

IL-6: Interleukin-6

IL-8: Interleukin-8

IL-18: Interleukin-18

IL-1 $\beta$ : Interleukin 1 beta

iNOS: Inducible nitric oxide synthase

LPS: Lipopolysaccharide

$\mathrm{LTB}_{4}$ : Leukotriene $\mathrm{B}_{4}$

MAPK: Mitogen-activated protein kinase pathways

MDA: Malondialdehyde

MPO: Myeloperoxidase

NSAIDs: Nonsteroidal anti-inflammatory drugs

NF- $\kappa$ B: $\quad$ Nuclear factor kappa B

NO: $\quad$ Nitric oxide

OVA: Ovalbumin 


$\begin{array}{ll}\text { OVX: } & \text { Ovariectomized } \\ \text { PGE: } & \text { Prostaglandins } \\ \text { PGE2: } & \text { Prostaglandins-2 } \\ \text { PMN: } & \text { Polymorphonuclear } \\ \text { RANKL: } & \text { Receptor activator of NF- } \kappa \text { B ligand } \\ \text { SI: } & \text { Stimulation indices } \\ \text { SOD: } & \text { Dismutase } \\ \text { TH1: } & \text { T helper type } 1 \\ \text { TH2: } & \text { T helper type } 2 \\ \text { TNF- } \alpha: & \text { Tumor necrosis factor } \alpha \\ \text { TNBC: } & \text { Cytotoxicity against breast cancer cells } \\ \text { TPA: } & \text { 12-O-tetradecanoylphorbol-13-acetate } \\ \text { TRAP: } & \text { Acid phosphatase assay. }\end{array}$

\section{Conflicts of Interest}

The authors declare that there is no conflict of interest regarding the publication of this paper.

\section{Acknowledgments}

This work was supported by the Brazilian agencies: Conselho Nacional de Desenvolvimento Científico e Tecnológico (CNPq) and Coordenação de Aperfeiçoamento de Pessoal de Nível Superior (CAPES).

\section{References}

[1] P. Zhang, E. Zhang, M. Xiao, C. Chen, and W. Xu, "Study of anti-inflammatory activities of $\alpha$-d-glucosylated eugenol," Archives of Pharmacal Research, vol. 36, no. 1, pp. 109-115, 2013.

[2] H. Zhang, X. Chen, and J. J. He, "Pharmacological action of clove oil and its application in oral care products," Oral Care Industry, vol. 19, pp. 23-24, 2009.

[3] D. Chatterjee and P. Bhattacharjee, "Use of eugenol-lean clove extract as a flavoring agent and natural antioxidant in mayonnaise: product characterization and storage study," Journal of Food Science and Technology, vol. 52, no. 8, pp. 4945-4954, 2015.

[4] K. G. Lee and T. Shibamoto, "Antioxidant properties of aroma compounds isolated from soybeans and mung beans," Journal of Agricultural and Food Chemistry, vol. 48, no. 9, pp. 42904293, 2000.

[5] G. Charalambous, Ed., The Quality of Foods and Beverages V1: Chemistry and Technology, Elsevier, 2012.

[6] M. Marotti, R. Piccaglia, and E. Giovanelli, "Differences in essential oil composition of basil (Ocimum basilicum L.) Italian cultivars related to morphological characteristics," Journal of Agricultural and Food Chemistry, vol. 44, no. 12, pp. 3926-3929, 2005.

[7] W. Bin-Nan, H. Tsong-Long, L. Ching-Fong, and C. Ing-Jun, "Vaninolol: a new selective $\beta 1$-adrenoceptor antagonist derived from vanillin," Biochemical Pharmacology, vol. 48, no. 1, pp. 101-109, 1994.

[8] D. P. Bezerra, G. C. G. Militão, M. C. de Morais, and D. P. de Sousa, "The dual antioxidant/prooxidant effect of eugenol and its action in cancer development and treatment," Nutrients, vol. 9, no. 12, p. 1367, 2017.

[9] M. J. Jordán, K. Tandon, P. E. Shaw, and K. L. Goodner, "Aromatic profile of aqueous banana essence and banana fruit by gas chromatography-mass spectrometry (GC-MS) and gas chromatography-olfactometry (GC-O)," Journal of Agricultural and Food Chemistry, vol. 49, no. 10, pp. 4813-4817, 2001.

[10] M. J. N. Diógenes and F. J. A. Matos, "Dermatite de contato por plantas (DCP)," Anais Brasileiros De Dermatologia, vol. 74, no. 6, pp. 629-634, 1999.

[11] M. Sedighi, A. Nazari, M. Faghihi et al., "Protective effects of cinnamon bark extract against ischemia-reperfusion injury and arrhythmias in rat," Phytotherapy Research, vol. 32, no. 10, pp. 1983-1991, 2018.

[12] S. J. Lee and K. G. Lee, "Inhibitory effects of volatile antioxidants found in various beans on malonaldehyde formation in horse blood plasma," Food and Chemical Toxicology, vol. 43, no. 4, pp. 515-520, 2005.

[13] A. L. Dawidowicz and M. Olszowy, "Does antioxidant properties of the main component of essential oil reflect its antioxidant properties? The comparison of antioxidant properties of essential oils and their main components," Natural Product Research, vol. 28, no. 22, pp. 1952-1963, 2014.

[14] D.-Y. Kim, K.-J. Won, D. I. Hwan, S. M. Park, B. Kim, and H. M. Lee, "Chemical composition, antioxidant and antimelanogenic activities of essential oils from Chrysanthemum boreale Makino at different harvesting stages," Chemistry of Biodiversity, vol. 15, no. 2, article e1700506, 2018.

[15] X. Han and T. L. Parker, "Anti-inflammatory activity of clove (Eugenia caryophyllata) essential oil in human dermal fibroblasts," Pharmaceutical Biology, vol. 55, no. 1, pp. 1619-1622, 2017.

[16] L. Ferrero-Miliani, O. H. Nielsen, P. S. Andersen, and S. E. Girardin, "Chronic inflammation: importance of NOD2 and NALP3 in interleukin-1 $\beta$ generation," Clinical and Experimental Immunology, vol. 147, no. 2, pp. 227-235, 2007.

[17] R. de Cássia da Silveira e Sá, L. N. Andrade, and D. P. de Sousa, "A review on anti-inflammatory activity of monoterpenes," Molecules, vol. 18, no. 1, pp. 1227-1254, 2013.

[18] R. Cássia da Silveira e Sá, L. N. Andrade, and D. P. de Sousa, "Anti-inflammation activities of essential oil and its constituents from indigenous cinnamon (Cinnamomum osmophloeum) twigs," Bioresource Technology, vol. 99, no. 9, pp. 3908-3913, 2008.

[19] M. J. Stone, "Regulation of chemokine-receptor interactions and functions," International Journal of Molecular Sciences, vol. 18, no. 11, article 2415, 2017.

[20] I. T. Nizamutdinova, G. F. Dusio, O. Y. Gasheva et al., "Mast cells and histamine are triggering the NF- $\kappa \mathrm{B}$-mediated reactions of adult and aged perilymphatic mesenteric tissues to acute inflammation," Aging, vol. 8, no. 11, article 3065, 3090 pages, 2016.

[21] J. Wang, Y. T. Liu, L. Xiao, L. Zhu, Q. Wang, and T. Yan, "Anti-inflammatory effects of apigenin in lipopolysaccharideinduced inflammatory in acute lung injury by suppressing COX-2 and NF-kB pathway," Inflammation, vol. 37, no. 6, pp. 2085-2090, 2014.

[22] F. Polesso, M. Sarker, A. Anderson, D. C. Parker, and S. E. Murray, "Constitutive expression of NF- $\kappa \mathrm{B}$ inducing kinase in regulatory $\mathrm{T}$ cells impairs suppressive function and promotes instability and pro-inflammatory cytokine production," Scientific Reports, vol. 7, no. 1, article 14779, 2017.

[23] S. S. Islam, I. Al-Sharif, A. Sultan, A. Al-Mazrou, A. Remmal, and A. Aboussekhra, "Eugenol potentiates cisplatin anticancer activity through inhibition of ALDH-positive breast 
cancer stem cells and the NF- $\kappa \mathrm{B}$ signaling pathway," Molecular Carcinogenesis, vol. 57, no. 3, pp. 333-346, 2018.

[24] B. L. Bermas, "Non-steroidal anti inflammatory drugs, glucocorticoids and disease modifying anti-rheumatic drugs for the management of rheumatoid arthritis before and during pregnancy," Current Opinion in Rheumatology, vol. 26, no. 3, pp. 334-340, 2014.

[25] J. D. Rajput, S. D. Bagul, U. D. Pete, C. M. Zade, S. B. Padhye, and R. S. Bendre, "Perspectives on medicinal properties of natural phenolic monoterpenoids and their hybrids," Molecular Diversity, vol. 22, no. 1, pp. 225-245, 2018.

[26] D. P. Sousa, Medicinal Essential Oils: Chemical, Pharmacological and Therapeutic Aspects, Nova Science Publishers, 2012.

[27] R. de Cássia da Silveira e Sá, L. N. Andrade, R. dos Reis Barreto de Oliveira, and D. P. de Sousa, "A review on antiinflammatory activity of phenylpropanoids found in essential oils," Molecules, vol. 19, no. 2, pp. 1459-1480, 2014.

[28] S. S. Kim, O. J. Oh, H. Y. Min et al., "Eugenol suppresses cyclooxygenase-2 expression in lipopolysaccharide-stimulated mouse macrophage RAW264. 7 cells," Life Sciences, vol. 73, no. 3, pp. 337-348, 2003.

[29] E. Dervis, A. Yurt Kilcar, E. I. Medine et al., "In vitro incorporation of radioiodinated eugenol on adenocarcinoma cell lines (Caco2, MCF7, and PC3)," Cancer Biotherapy \& Radiopharmaceuticals, vol. 32, no. 3, pp. 75-81, 2017.

[30] S. F. Hamed, Z. Sadek, and A. Edris, "Antioxidant and antimicrobial activities of clove bud essential oil and eugenol nanoparticles in alcohol-free microemulsion," Journal of Oleo Science, vol. 61, no. 11, pp. 641-648, 2012.

[31] E. Darvishi, M. Omidi, A. A. S. Bushehri, A. Golshani, and M. L. Smith, "The antifungal eugenol perturbs dual aromatic and branched-chain amino acid permeases in the cytoplasmic membrane of yeast," PLoS One, vol. 8, no. 10, p. e76028, 2013.

[32] J.-P. Dai, X. F. Zhao, J. Zeng et al., "Drug screening for autophagy inhibitors based on the dissociation of Beclin1-Bcl2 complex using BiFC technique and mechanism of eugenol on anti-influenza A virus activity," PLoS One, vol. 8, no. 4, article e61026, 2013.

[33] Y. A. Taher, A. M. Samud, F. E. El-Taher et al., "Experimental evaluation of anti-inflammatory, antinociceptive and antipyretic activities of clove oil in mice," Libyan Journal of Medicine, vol. 10, no. 1, article 28685, 2015.

[34] H. Tsuchiya, "Anesthetic agents of plant origin: a review of phytochemicals with anesthetic activity," Molecules, vol. 22, no. 8, p. 1369, 2017.

[35] B. Baldisserotto, T. V. Parodi, and E. D. Stevens, "Lack of postexposure analgesic efficacy of low concentrations of eugenol in zebrafish," Veterinary Anaesthesia and Analgesia, vol. 45, no. 1, pp. 48-56, 2018.

[36] R. Perez-Roses, E. Risco, R. Vila, P. Penalver, and S. Canigueral, "Biological and nonbiological antioxidant activity of some essential oils," Journal of Agricultural and Food Chemistry, vol. 64, no. 23, pp. 4716-4724, 2016.

[37] L. L. Zhang, L. F. Zhang, J. G. Xu, and Q. P. Hu, "Comparison study on antioxidant, DNA damage protective and antibacterial activities of eugenol and isoeugenol against several foodborne pathogens," Food \& Nutrition Research, vol. 61, no. 1, article 1353356, 2017.

[38] U. K. Sharma, A. K. Sharma, and A. K. Pandey, "Medicinal attributes of major phenylpropanoids present in cinnamon,"
BMC Complementary and Alternative Medicine, vol. 16, no. 1, p. 156, 2016.

[39] B. Yogalakshmi, P. Viswanathan, and C. V. Anuradha, "Investigation of antioxidant, anti-inflammatory and DNAprotective properties of eugenol in thioacetamide-induced liver injury in rats," Toxicology, vol. 268, no. 3, pp. 204-212, 2010.

[40] G. Kaur, M. Athar, and M. S. Alam, "Eugenol precludes cutaneous chemical carcinogenesis in mouse by preventing oxidative stress and inflammation and by inducing apoptosis," Molecular Carcinogenesis, vol. 49, no. 3, pp. 290-301, 2010.

[41] X. Huang, Y. Liu, Y. Lu, and C. Ma, “Anti-inflammatory effects of eugenol on lipopolysaccharide-induced inflammatory reaction in acute lung injury via regulating inflammation and redox status," International Immunopharmacology, vol. 26, no. 1, pp. 265-271, 2015.

[42] P. Patlevič, J. Vašková, P. Švorc Jr, L. Vaško, and P. Švorc, "Reactive oxygen species and antioxidant defense in human gastrointestinal diseases," Integrative Medicine Research, vol. 5, no. 4, pp. 250-258, 2016.

[43] A. Ayala, M. F. Muñoz, and S. Argüelles, "Lipid peroxidation: production, metabolism, and signaling mechanisms of malondialdehyde and 4-hydroxy-2-nonenal," Oxidative Medicine and Cellular Longevity, vol. 2014, Article ID 360438, 31 pages, 2014.

[44] N. García, C. Zazueta, and L. Aguilera-Aguirre, "Oxidative stress and inflammation in cardiovascular disease," Oxidative Medicine and Cellular Longevity, vol. 2017, Article ID 5853238, 2 pages, 2017.

[45] S. K. Biswas, J. B. Lopes De Faria, S. K. Biswas, and J. B. Lopes De Faria, "Which comes first: renal inflammation or oxidative stress in spontaneously hypertensive rats?," Free Radical Research, vol. 41, no. 2, pp. 216-224, 2007.

[46] A. Ambade and P. Mandrekar, "Oxidative stress and inflammation: essential partners in alcoholic liver disease," International Journal of Hepatology, vol. 2012, Article ID 853175, 9 pages, 2012.

[47] S. Reuter, S. C. Gupta, M. M. Chaturvedi, and B. B. Aggarwal, "Oxidative stress, inflammation, and cancer: how are they linked?," Free Radical Biology and Medicine, vol. 49, no. 11, pp. 1603-1616, 2010.

[48] T. Hussain, B. Tan, Y. Yin, F. Blachier, M. C. B. Tossou, and N. Rahu, "Oxidative stress and inflammation: what polyphenols can do for us?," Oxidative Medicine and Cellular Longevity, vol. 2016, Article ID 7432797, 9 pages, 2016.

[49] H. U. von Andrian, J. D. Chambers, L. M. McEvoy, R. F. Bargatze, K. E. Arfors, and E. C. Butcher, "Two-step model of leukocyte-endothelial cell interaction in inflammation: distinct roles for LECAM-1 and the leukocyte beta 2 integrins in vivo," Proceedings of the National Academy of Sciences, vol. 88, no. 17, pp. 7538-7542, 1991.

[50] C. F. Estevão-Silva, R. Kummer, F. C. Fachini-Queiroz et al., "Anethole and eugenol reduce in vitro and in vivo leukocyte migration induced by fMLP, $\mathrm{LTB}_{4}$, and carrageenan," Journal of Natural Medicines, vol. 68, no. 3, pp. 567-575, 2014.

[51] C. Pan and Z. Dong, "Antiasthmatic effects of eugenol in a mouse model of allergic asthma by regulation of vitamin $\mathrm{D}_{3}$ upregulated protein $1 / \mathrm{NF}-\kappa \mathrm{B}$ pathway," Inflammation, vol. 38, no. 4, pp. 1385-1393, 2015.

[52] C. B. Magalhães, D. R. Riva, L. J. DePaula et al., "In vivo antiinflammatory action of eugenol on lipopolysaccharide- 
induced lung injury," Journal of Applied Physiology, vol. 108, no. 4, pp. 845-851, 2010.

[53] W. A. Zin, A. G. L. S. Silva, C. B. Magalhães et al., "Eugenol attenuates pulmonary damage induced by diesel exhaust particles," Journal of Applied Physiology, vol. 112, no. 5, pp. 911917, 2012.

[54] D. M. Abd el Motteleb, S. A. Selim, and A. M. Mohamed, "Differential effects of eugenol against hepatic inflammation and overall damage induced by ischemia/re-perfusion injury," Journal of Immunotoxicology, vol. 11, no. 3, pp. 238-245, 2014.

[55] K. Mnafgui, R. Hajji, F. Derbali et al., "Anti-inflammatory, antithrombotic and cardiac remodeling preventive effects of eugenol in isoproterenol-induced myocardial infarction in Wistar rat," Cardiovascular Toxicology, vol. 16, no. 4, pp. 336-344, 2016.

[56] G. Arango Duque and A. Descoteaux, "Macrophage cytokines: involvement in immunity and infectious diseases," Frontiers in Immunology, vol. 5, p. 491, 2014.

[57] J. L. Yeh, J. H. Hsu, Y. S. Hong et al., "Eugenolol and glycerylisoeugenol suppress LPS-induced iNOS expression by downregulating NF- $\kappa$ B AND AP-1 through inhibition of MAPKS and $\mathrm{AKT} / \mathrm{I} \kappa \mathrm{B} \alpha$ signaling pathways in macrophages," International Journal of Immunopathology and Pharmacology, vol. 24, no. 2, pp. 345-356, 2011.

[58] M. de Paula Porto, G. N. Da Silva, B. C. O. Luperini et al., "Citral and eugenol modulate DNA damage and proinflammatory mediator genes in murine peritoneal macrophages," Molecular Biology Reports, vol. 41, no. 11, pp. 70437051, 2014.

[59] V. Deepak, A. Kasonga, M. C. Kruger, and M. Coetzee, "Inhibitory effects of eugenol on RANKL-induced osteoclast formation via attenuation of NF- $\kappa \mathrm{B}$ and MAPK pathways," Connective Tissue Research, vol. 56, no. 3, pp. 195-203, 2015.

[60] H. M. Abuohashish, D. A. Khairy, M. M. Abdelsalam, A. Alsayyah, M. M. Ahmed, and S. S. Al-Rejaie, "In-vivo assessment of the osteo-protective effects of eugenol in alveolar bone tissues," Biomedicine \& Pharmacotherapy, vol. 97, pp. 1303-1310, 2018.

[61] S. Faizel, S. Thomas, V. Yuvaraj, S. Prabhu, and G. Tripathi, "Comparision between neocone, alvogyl and zinc oxide eugenol packing for the treatment of dry socket: a double blind randomised control trial," Journal of Maxillofacial and Oral Surgery, vol. 14, no. 2, pp. 312-320, 2015.

[62] A. Martínez-Herrera, A. Pozos-Guillén, S. Ruiz-Rodríguez, A. Garrocho-Rangel, A. Vértiz-Hernández, and D. M. Escobar-García, "Effect of 4-allyl-1-hydroxy-2-methoxybenzene (eugenol) on inflammatory and apoptosis processes in dental pulp fibroblasts," Mediators of Inflammation, vol. 2016, Article ID 9371403, 7 pages, 2016.

[63] A. Hussain, K. Brahmbhatt, A. Priyani, M. Ahmed, T. A. Rizvi, and C. Sharma, "Eugenol enhances the chemotherapeutic potential of gemcitabine and induces anticarcinogenic and anti-inflammatory activity in human cervical cancer cells," Cancer Biotherapy and Radiopharmaceuticals, vol. 26, no. 5, pp. 519-527, 2011.

[64] F. Esmaeili, S. Rajabnejhad, A. R. Partoazar et al., "Antiinflammatory effects of eugenol nanoemulsion as a topical delivery system," Pharmaceutical Development and Technology, vol. 21, no. 7, pp. 887-893, 2016.

[65] J. S. Jesudasan, P. U. A. Wahab, and M. R. M. Sekhar, "Effectiveness of $0.2 \%$ chlorhexidine gel and a eugenol-based paste on postoperative alveolar osteitis in patients having third molars extracted: a randomised controlled clinical trial," British Journal of Oral and Maxillofacial Surgery, vol. 53, no. 9, pp. 826-830, 2015.

[66] Y. H. Shih, D. J. Lin, K. W. Chang et al., "Evaluation physical characteristics and comparison antimicrobial and antiinflammation potentials of dental root canal sealers containing hinokitiol in vitro," PLoS One, vol. 9, no. 6, article e94941, 2014.

[67] M. Escobar-García, K. Rodríguez-Contreras, S. Ruiz-Rodríguez, M. Pierdant-Pérez, B. Cerda-Cristerna, and A. PozosGuillén, "Eugenol toxicity in human dental pulp fibroblasts of primary teeth," Journal of Clinical Pediatric Dentistry, vol. 40, no. 4, pp. 312-318, 2016. 


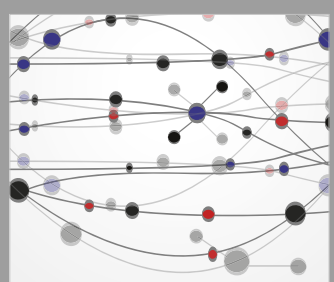

The Scientific World Journal
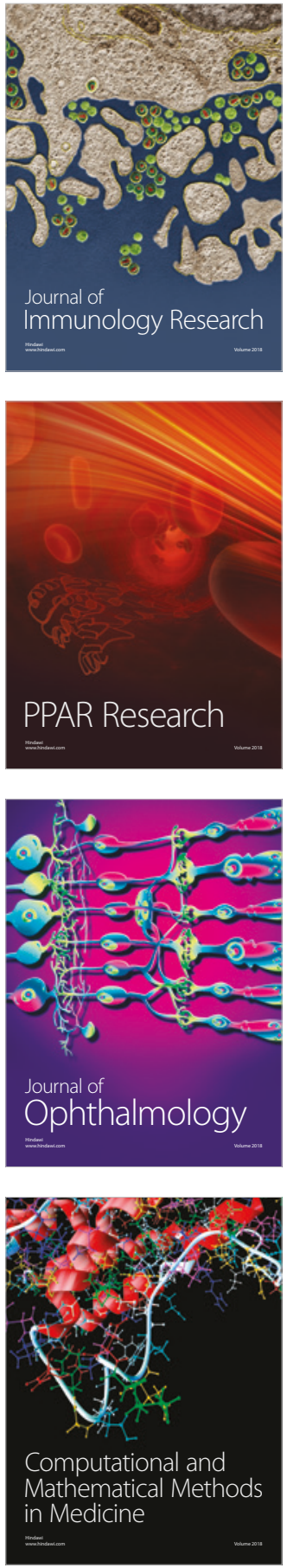

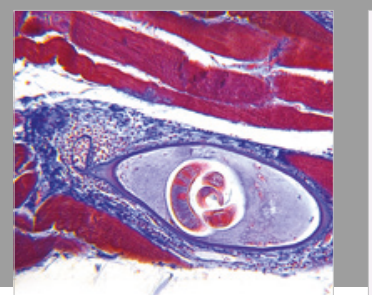

Gastroenterology Research and Practice

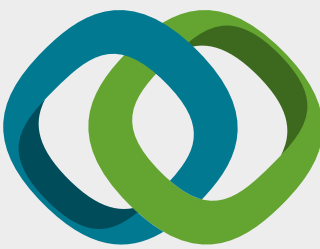

\section{Hindawi}

Submit your manuscripts at

www.hindawi.com
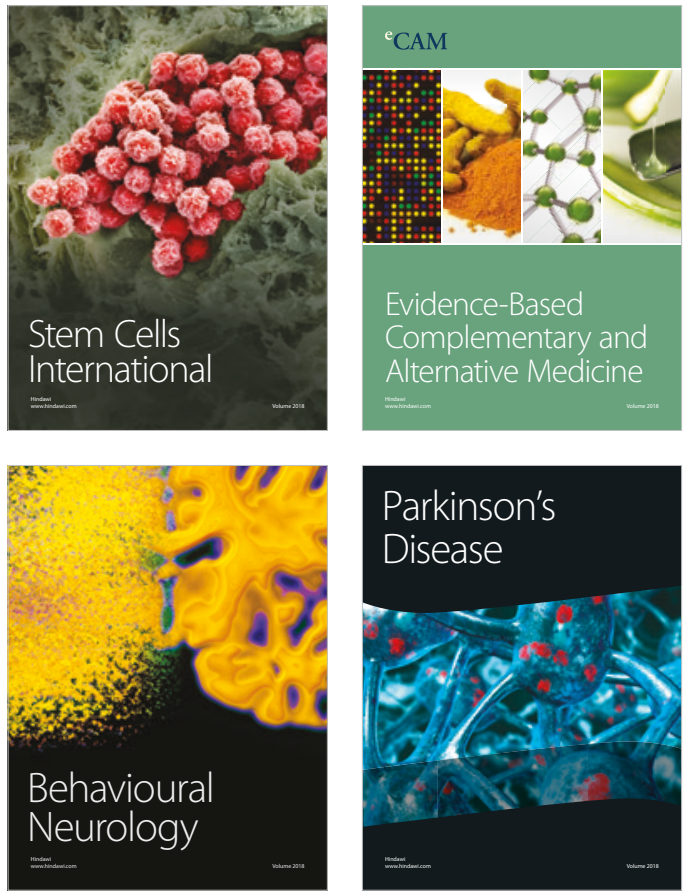

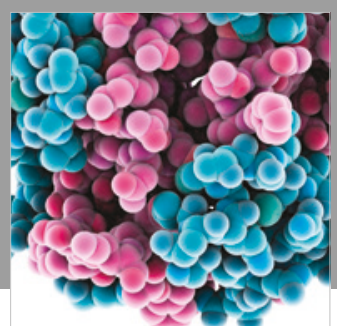

ournal of

Diabetes Research

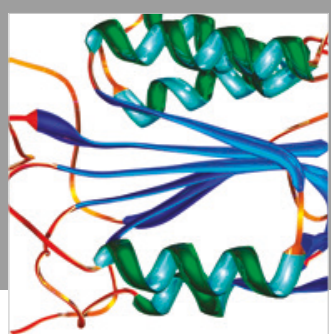

Disease Markers
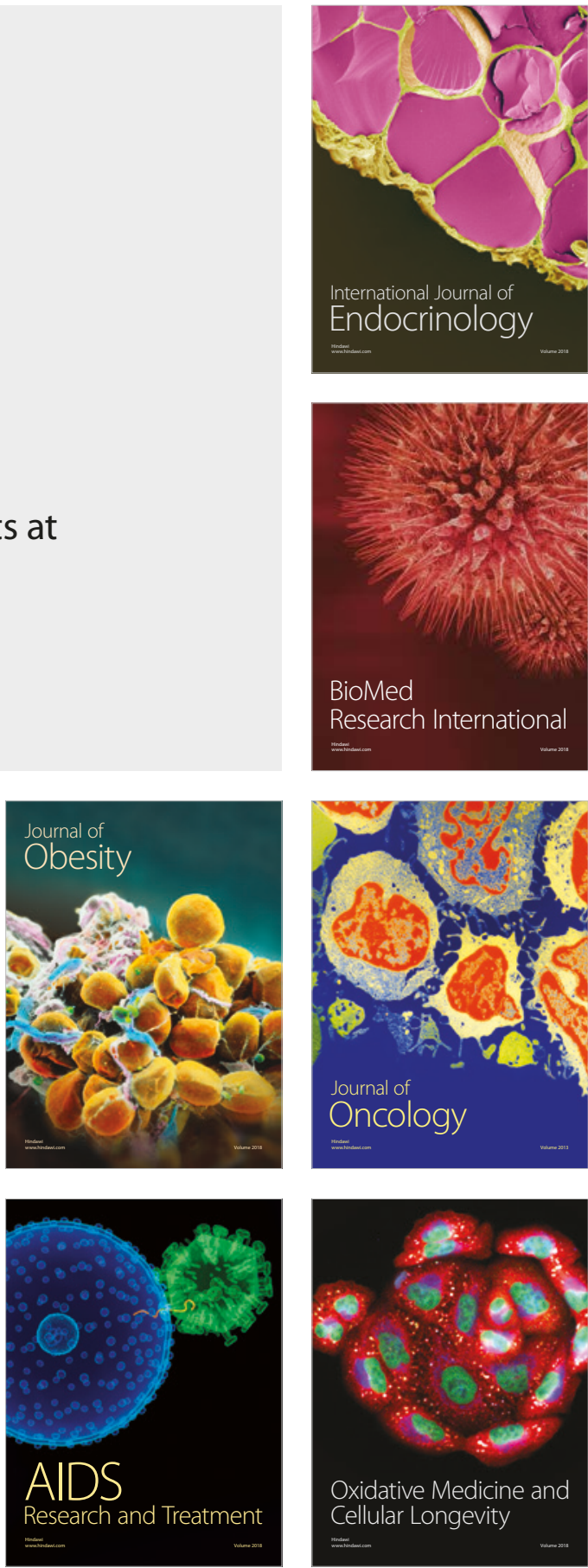